\title{
Comparison of Mirror and Video Methods in Increasing Caregiver Knowledge in Treating Clients Halusination
}

\author{
Bambang Eryanto ${ }^{1}$, Shelly Iskandar ${ }^{2}$, Taty Hernawaty ${ }^{3}$ \\ Faculty of Nursing Universitas Padjadjaran \\ Email:benkbenkners@gmail.com
}

Submitted: 28-12-2018 Accepted: 27-7-2018 Published: 11-8-2018

\begin{abstract}
Efforts to improve caregiver's knowledge on hallucination is by providing an education the caregivers. Enhancing such knowledge can be carried out by different methods, include lecture and watching video methods. The purpose of the present research was to compare the effectiveness of lecture and watching video method in enhancing caregiver's knowledge on hallucination. The research used a quasi-experiment method with a pretest and posttest group design, with the research sample was 60 . The sampling technique used was a total sampling. The scores of caregiver's knowledge were determined by a questionnaire of knowledge on hallucination that was self-developed by validity test $(0.707)$ and reliability test $(0.968)$. The data obtained was then tested by using Independent Sample T-test, Mann-Whitney test, and Wilcoxon test. The result of pretest of caregiver's knowledge before the intervention showed that there was no difference between intervention and control group ( $\mathrm{p}$-value $=0.624$ ), while result of posttest of caregiver's knowledge after the intervention showed that there was a significant difference between lecture group and video group ( $p$-value $=0.000$ ). The research findings revealed that there was a significant increase in the scores of knowledge for both methods ( $p$-value $=0.000)$, but the increase of video group's knowledge score was higher (4.23) than that of lecture group (2.57). The conclusion of the research was that wathing video method was more effective than lecture method in enhancing caregiver's knowledge so that video can be used as an alternative method for mental health education.
\end{abstract}

Keywords: Caregiver, hallucination, lecture method, video method, knowledge. 
Bambang Eryanto: Comparison of Mirror and Video Methods in Increasing Caregiver Knowledge

\section{Introduction}

The problem of mental disorders is a health problem that must be dealt with seriously, especially in a community that is still unfamiliar with mental disorders and has a low economic income. Maramis (2014) suggested that social relations and worsening economic problems and high workloads could be a trigger for mental disorders. Mental disorders are defined as mental states that are not related to reality (Stuart, 2016). Data from the World Health Organization (WHO) in 2016 obtained data as many as twentyone million people in the world affected by schizophrenia and needed immediate treatment to find a solution to this problem by mental health experts in particular (Ministry of Health RI, 2016).

In Indonesia, the results of Basic Health Research (Riskesdas) in 2013 showed that the prevalence of severe mental disorders was 1.7 per 1,000 population. Of the mental disorder clients, $14.3 \%$ or about 57,000 people have been or are being put in a supply. The figure of rural income is $18.2 \%$. This figure is higher than the figure in urban areas, which is $10.7 \%$. It can be concluded that there is more happening in rural areas (Mboi, 2016).

Patients with mild to severe mental disorders in West Java currently reach 465,975 people. This number increased significantly from 2012 with 296,943. This indicates that people with mental disorders in West Java rose by $63 \%$. Trends in mental disorders are expected to increase every year (Pitaloka, 2016).

Schizophrenia is a mental disorder that is categorized as the most serious psychic disorder because it can cause a decline in human function in carrying out daily life activities (Jaste \& Mueser, 2008). Mental disorders are complex neurobiological brain diseases that affect a person's ability to understand and process information (Stuart, 2016). Schizophrenia clients also experience a decrease in independence in self-care, social functions, so they need family help (Kartikasari, 2017).

Stuart and Laraia (2013) stated that as many as $20 \%$ of clients with schizophrenia experience auditory and visual hallucinations simultaneously, $70 \%$ experience auditory hallucinations, $20 \%$ experience visual hallucinations, and 10\% experience other hallucinations. Based on these data it is known that the type of hallucination most clients suffer from schizophrenia is auditory hallucinations. In the schizophrenic client hallucinations are more than $60 \%$ the most dominant influencing it (Syriac, 2018).

Sulistiowati (2010) suggested that the participation of family members in the handling of client hallucinations becomes important, where the hallucination client begins the first interpersonal relationship in his environment is his own family. It is expected that families can help clients hallucinate in learning to develop the values, beliefs, attitudes and behavior of clients, so that clients will be ready to play a role in the community after hospitalization.

Suryani (2013) suggested that mental disorder is a journey of challenge or a challenging journey. Clients find it difficult to recover right away and need a long process of healing. So it needs continuous assistance from the caregiver until the client is truly independent. Caregiver is an individual who generally caring for and supporting clients of hallucinations in carrying out their daily activities which have a lot of time used to interact with hallucination clients (Awad \& Voruganti, 2008). When the client is at home the support of the caregiver, family and the surrounding environment is needed so that the client can undergo a recovery or recovery process.

Metkono (2014) suggested that in caring for family members with hallucinations can cause a burden for the caregiver. The burden can be an objective burden and subjective burden. The caregiver's burden can reduce the caregiver's ability to care for clients. The condition of the client who is relapsed will heighten the perceived burden. The inability of the caregiver to treat can cause bad behavior. This is due to the lack of caregiver's knowledge in caring for clients in his home.

Health problems suffered by one family member can cause stress for other family members, especially the primary caregiver. For that, caregiver needs to master coping skills to overcome the burden experienced in carrying out its role. Among the various aspects that play a role in achieving an 
Bambang Eryanto: Comparison of Mirror and Video Methods in Increasing Caregiver Knowledge

effective coping for the caregiver is the need for good and correct knowledge and information. That is, the schizophrenia caregiver needs to have sufficient information about the schizophrenia disorder itself and to know what burden is borne by the patient's family and how to overcome it (Jusuf, 2014). It is expected that with sufficient caregiver knowledge, it can be used as the initial foundation for the formation of changes in the attitude and behavior of the caregiver itself in caring for the hallucinatory clients (Sunaryo, 2004).

Efforts to improve the caregiver's knowledge in caring for hallucination clients are by providing health education to the caregiver itself, so that there is a significant change in knowledge, attitudes and skills of the caregiver in caring for hallucinative clients at home. Health education is a person's learning experience and what action plans will be taken to care for themselves individually or jointly, or act as decision makers to care for the health of others and their environment (Keliat, 2002). Farkhah's research (2017) the quality of caregiver's life is the most dominant factor in the recovery of schizophrenia clients. The lecture method is an educational method that has long been used to convey ideas, ideas, and new information to the desired target. The drawback of the lecture method is that the delivery is only one direction, boring, material that is too long is difficult to understand and students are more passive (Setiawati, 2008).

Research on the effectiveness of methods to improve family knowledge has been carried out on client caregivers with various diseases. Research conducted on 350 adult women in Odogbolu (intervened) and Ikenne (as controls) in the Nigeria Ogun area, showed that health education using film media was effective in creating awareness and increasing adult women's knowledge and perceptions of cervical cancer and screening (Abiodun, 2014) According to Arsyad (2007) explained that video film is one of the media for educational purposes. Video playback can describe objects or processes correctly, teaching skills that can be presented repeatedly.

This research was carried out in Jatibarang Health Center, because in Puskesmas this was the highest case in the Indramayu region. Based on the recap of the soul case data of the community in Indramayu there are 236 cases of mental disorders in the Jatibarang Health Center (Indramayu District Health Office, 2014). Jatibarang Public Health Center once conducted mental health education with the lecture method in 2014, but the evaluation shows that there has not been much help for the caregiver in increasing knowledge in caring for clients in his home, this is because health education is only using lecture methods, so researchers are interested in comparison of mental health education methods using lecture methods and video methods to improve caregiver's knowledge about how to care for hallucinatory clients in the Jatibarang Community Health Center work area.

\section{Method}

This type of research is a quantitative quasiexperimental study with a design of two group pretest-posttest design. The design of this study involved two groups of respondents. Each respondent group consists of 30 people. The selection of the respondent group was done randomly before being intervened, with a draw or shuffle of the respondent's name.

Table 1 Overview of Respondent Characteristics

\begin{tabular}{|c|c|c|c|c|c|c|}
\hline \multirow{2}{*}{ No } & \multirow{2}{*}{$\begin{array}{c}\text { Characteristics of } \\
\text { Respondents }\end{array}$} & \multicolumn{2}{|c|}{ Lecture $(\mathrm{n}=30)$} & \multicolumn{2}{|c|}{ Video $(\mathrm{n}=30)$} & \multirow{2}{*}{$\begin{array}{c}\text { Result } \mathrm{P} \\
\text { Value }\end{array}$} \\
\cline { 3 - 6 } & & Frequency & $(\%)$ & Frequency & $(\%)$ & \\
\hline 1 & Gender & & & & & \\
\hline & Male & 10 & 33.3 & 13 & 43.3 & 0.595 \\
\hline & Female & 20 & 66.7 & 17 & 56.7 & \\
\hline 2 & Age & & & & & \\
\hline
\end{tabular}


Bambang Eryanto: Comparison of Mirror and Video Methods in Increasing Caregiver Knowledge

\begin{tabular}{|c|c|c|c|c|c|c|}
\hline & $\begin{array}{c}\text { Early adults (18-44 } \\
\text { year) }\end{array}$ & 13 & 43.4 & 6 & 20 & 0.111 \\
\hline & $\begin{array}{l}\text { Middle Adult (45-59 } \\
\text { year) }\end{array}$ & 10 & 33.3 & 17 & 56.7 & \\
\hline & Elderly (60-74 year) & 7 & 23.3 & 7 & 23.3 & \\
\hline \multirow[t]{6}{*}{3} & Education & & & & & \\
\hline & Unschool & 3 & 10 & 6 & 20 & 0.698 \\
\hline & $\begin{array}{c}\text { Based school / } \\
\text { equivalent }\end{array}$ & 8 & 26.7 & 5 & 16.7 & \\
\hline & $\begin{array}{c}\text { Junior high school / } \\
\text { equivalent }\end{array}$ & 7 & 23.3 & 5 & 16.7 & \\
\hline & $\begin{array}{l}\text { Senior High school / } \\
\text { equivalent }\end{array}$ & 10 & 33.3 & 12 & 40 & \\
\hline & University / equivalent & 2 & 6.7 & 2 & 6.7 & \\
\hline \multirow[t]{5}{*}{4} & $\begin{array}{c}\text { Related Status with } \\
\text { Client }\end{array}$ & & & & & \\
\hline & Mother & 14 & 46.7 & 12 & 40 & 0.417 \\
\hline & Father & 4 & 13.3 & 8 & 26.7 & \\
\hline & Womb brother & 7 & 23.3 & 8 & 26.7 & \\
\hline & Unwomb brother & 5 & 16.7 & 2 & 6.7 & \\
\hline \multirow[t]{3}{*}{5} & Working Status & & & & & \\
\hline & Work & 19 & 63.3 & 18 & 60 & 1.000 \\
\hline & No Work & 11 & 36.3 & 12 & 40 & \\
\hline \multirow[t]{4}{*}{6} & Client care duration & & & & & \\
\hline & $<1$ Year & 2 & 6.7 & 3 & 10 & 0.865 \\
\hline & 1-3 Year & 6 & 20 & 5 & 16.7 & \\
\hline & $>3$ Year & 22 & 73.3 & 22 & 73.3 & \\
\hline
\end{tabular}

Table 2 Results of Average Caregiver Knowledge Before Given Interventions

\begin{tabular}{|c|c|c|c|c|c|}
\hline \multirow{3}{*}{ Measuring } & \multicolumn{4}{|c|}{ Group } & \multirow{2}{*}{$\begin{array}{c}\text { Result } \mathrm{p} \\
\text { Value }\end{array}$} \\
\cline { 2 - 5 } & \multicolumn{3}{|c|}{ Lecture } & \multicolumn{2}{c|}{ Video } \\
\cline { 2 - 5 } & Mean & SD & Mean & SD & \\
\hline Knowledge Pre test (0-12) & 7.73 & 1.258 & 7.57 & 1.357 & 0.624 \\
\hline
\end{tabular}

Table 3 Results of Average Caregiver Knowledge After Given Interventions

\begin{tabular}{|l|c|c|c|c|c|}
\hline \multirow{3}{*}{ Measuring } & \multicolumn{4}{|c|}{ Group } & \multirow{2}{*}{ Result $\mathrm{p}$ Value } \\
\cline { 2 - 5 } & \multicolumn{2}{|c|}{ Lecture } & \multicolumn{2}{c|}{ Video } \\
\cline { 2 - 5 } & Mean & SD & Mean & SD & \\
\hline Knowledge Post test (0-12) & 10.30 & 1.512 & 11.80 & 0.407 & 0.000 \\
\hline
\end{tabular}

Table 4 Results of Average Caregiver Knowledge between Before and After Given Interventions in Lecture and Video Groups

\begin{tabular}{|c|c|c|c|c|}
\hline Group & Mean & SD & N & Result P value \\
\hline Lecture & & & & \\
\hline Pre test $(0-12)$ & 7.73 & 1.258 & 30 & 0.000 \\
\hline Post test $(0-12)$ & 10.30 & 1.512 & 30 & \\
\hline
\end{tabular}


Bambang Eryanto: Comparison of Mirror and Video Methods in Increasing Caregiver Knowledge

\begin{tabular}{|c|c|c|c|c|}
\hline Video & & & & \\
\hline Pre test $(0-12)$ & 7.57 & 1.357 & 30 & 0.000 \\
\hline Post test $(0-12)$ & 11.80 & 0.407 & 30 & \\
\hline
\end{tabular}

Based on Table 1 above, it is known that most of the respondents in the gender group of female respondents were 20 people $(66.7 \%)$ and in the video group of women were 17 people $(56 \%)$, while the age of respondents in the lecture group was dominant Adult (18-44 years old) ) as many as 13 people (43.4\%) and the dominant video group Mid (45-59 years) as many as 17 people (56.7\%). The education of the dominant lecture group respondents is SMA / equivalent as many as 10 respondents $(33.3 \%)$ and the dominant video group is also dominant in SMA / equivalent as many as 12 people $(40 \%)$.

Based on Table 2 above, it is known that the average knowledge of Pre Test Caregiver in the lecture group is 7.73, while the average knowledge of Pre Test Cergiver in the video group is 7.57. The results of the analysis using Independent $\mathrm{T}$ test obtained $\mathrm{p}$ value $=0.624>$ 0.05 , meaning that there was no difference in Pre test caregiver knowledge between the lecture group and the video group.

Based on Table 3 above it is known that the average post test Caregiver knowledge in the lecture group is 10.30 , while the average Ceregiver post test knowledge in the video group is 11.80 . The results of the analysis using the Mann-Whitney test obtained $\mathrm{p}$ value $=0.000<0.05$, meaning that there were significant differences in Post test caregiver knowledge between the lecture group and the video group.

Based on table 4 above, it is known that the average knowledge of pre test caregiver in the lecture group was 7.73, while the post test caregiver knowledge rose to 10.30. In the video group the average knowledge of the pre test caregiver was 7.57 , rising to 11.80 . The results of the analysis using the Wilcoxon test obtained a value of $0.000<0.05$, meaning that there were significant differences between the knowledge of the pre test caregiver and the post test caregiver knowledge of both the lecture group and the video group. But the increase in video group knowledge is higher than the increase in knowledge in the lecture group. This shows that the video method has a higher effectiveness than lectures in improving the caregiver's knowledge in caring for hallucinatory clients.

The material in the lecture was delivered by health educators in a language that was easily understood by the respondents, as well as the presence of two-way communication between health educators and questions from respondents making respondents more understanding of the material presented by the instructor. According to Wawan and Dewi (2010) factors that influence a person's level of knowledge come from the information he receives, with more information sources, one of which comes from health workers will increase wider knowledge.

The lecture method is an oral presentation of information. The advantage in the lecture method is that health educators can easily master and organize participants (audience), help the audience to listen accurately and critically, and if used correctly it will be able to stimulate and increase the audience's desire to behave in accordance with health education goals (Djamarah, 2007). Lecture is basically a direct communication between health educators and audiences. The health education process is a basis for transferring messages to be delivered by instructors to the target. Understanding gained by the audience will be in accordance with the target if the target of getting health education correctly, and of course as an instructor must have a deep understanding of the process of information dissemination, behavior change, to the process of social transformation (Nursalam \& Ferry, 2009).

These results are appropriate when related to the theory of Notoadmodjo (2007) explaining that health promotion strives for the behavior of individuals, groups or communities to have a positive influence on the maintenance and improvement of health. Williams (2010) said health education provides objective evidence for the development of a comprehensive health implementation program in maintaining one's health. Fidelis's (2013) study of the trust 
Bambang Eryanto: Comparison of Mirror and Video Methods in Increasing Caregiver Knowledge

and attitudes of leprosy patients in hospitals concluded that there was a relationship between patient trust in how to trust patients' attitudes in receiving leprosy care by health workers.

Before being given health education using video many caregivers who have less knowledge after being given health education using increased knowledge of caregiver knowledge to be well-informed. This is because the video used in the delivery of mental health education materials can attract the attention of caregivers. Notoadmodjo (2007) explained that in the process of health education besides being influenced by teaching materials and learning facilities, the use of health education methods and tools will influence the results desired by the teacher. The implementation of health education with a more effective video playback method can be because the video method has the advantage of being able to display an object or event as it really is. Video increases memory retention because it is more interesting and easy to remember (Sardiman, 2012).

Muhdhar (2012) mentions in his research that the provision of health education with video can improve the understanding of respondents. In line with Rani's research (2013) his research using video media obtained an increase in knowledge after health education. Both of these studies explain that health education with video methods will improve the caregiver's knowledge.

Video screening methods can shape students' knowledge, attitudes and behavior from the results of the capture of the five senses by students. As described by Maulana (2009), mentioning that the success of health education in changing behavior is also influenced by the capture of the five senses. The five senses that channel the most knowledge to the brain are eyes (approximately $75 \%$ to $87 \%$ ), while $13 \%$ to $25 \%$ of knowledge is acquired or channeled through other senses.

The effectiveness of mental health education between the intervened caregiver uses lectures and the caregiver who is intervened with video methods is both an increase in knowledge, the lecture and video methods are good to be used by researchers in delivering mental health education materials to caregivers because they can both increase the level of knowledge to the caregiver. However, the lowest increase in the knowledge score was for the caregiver who used the lecture method, because in the presentation of the material it was felt less attractive and the lecture material was only equipped with writing and drawing by the presenter. The highest level of knowledge is for caregivers who are given mental health education using video, because the caregiver can see the steps directly demonstrated by the model via video, can attract the attention of the caregiver to stay focused, the material, so that the caregiver will not feel bored and lose concentration.

On the other hand with the use of the lecture method, although respondents also experienced an increase in value from the results of the pre-test and post-test, but overall that by using the lecture method is still lower in value achieved by respondents. Lectures that have been delivered in simple language, but respondents only rely on the sense of hearing to study the mental health education material they have obtained. Unlike the case with video media, respondents did not only rely on the sense of hearing, but the sense of vision was also very important to help remember the material presented. The results of this study are in line with the research of Purnama (2013) which states that video media is more effective in increasing students' knowledge about drug hazard in Mojosongo Boyolali 3 Public Middle School.

This shows that basically the two methods used have the effectiveness of changing the knowledge of the caregiver caring for the hallucination client at home. In accordance with the objectives of health education, basically involves three things, namely increased knowledge (knowledge), changes in attitude (attitude), and skills or behavior (practices), which are associated with mental health problems in the community (Notoatmodjo, 2012).

\section{Conclusion}

This study aims to compare the effectiveness of mental health education using video and with methods that have been commonly 
Bambang Eryanto: Comparison of Mirror and Video Methods in Increasing Caregiver Knowledge

done (lectures). The sample that followed this study were 60 people (30 people in the video group and 30 people in the lecture group). The conclusions of the research that was obtained were video methods that were more effective in increasing the caregiver's knowledge about hallucinations in the provision of mental health education.

\section{Suggestion}

1) Puskesmas should be the executor of primary health services that directly relate to the community, can work with nursing education institutions to conduct training for health workers or nurses who hold mental programs in their health centers about providing mental health education using video methods as a basis for improving ability to provide more comprehensive health education by involving caregivers or families who have hallucinatory clients.

2) Mental health education using video methods can be applied in the mental nursing system, especially nursing community soul. Puskesmas as primary health care services can apply mental health education using video methods or provide videos on how to care for hallucinations clients through a home visit program to caregivers or families who have hallucination clients in their homes.

3) Based on the results of the above research can be continued research on the factors that influence the improvement of the caregiver's knowledge in caring for hallucination clients in his home. Research can also be continued with research on family attitudes and behavior in hallucinatory care.

\section{References}

Abiodun. (2014). Impact of health education intervention on knowledge and perception of cervical cancer and cervical screening uptake among adult women in rural communities in Nigeria. Retrieved from: http://bmcpublichealth.biomedcentral. com/articles/10.1186/1471-2458-14-814. html(15/9/14).

Arsyad, A. (2007). Media pembelajaran.
Jakarta: Raja Grafindo Persada.

Awad, A.G., \& Voruganti, L.N. (2008). The burden of schizophrenia on caregivers. Journal of Pharmacoeconomics, 26, 149162.

Djamarah, S.B. (2007). Strategi belajar mengajar. Jakarta: PT Rineka Cipta.

Dinkes Kabupaten Indramayu. (2014). Rekap data kasus gangguan jiwa di Indramayu. Tidak dipublikasikan.

Farkhah. (2017). Faktor caregiver dan kekambuhan klien skizofrenia. Jurnal Majalah Keperawatan, 5(1).

Fidelis, T.I. (2010). Beliefs and attitudes about leprosy of non-leprosy patients in a reversely integrated hospital. Asia Pacific Disability Rehabilitation Journal, 21(2).

Jaste \& Mueser. (2008). Clinical handbook of skizophrenia. The Guildford Press. New York. London.

Jusuf, L. (2014). Asesmen kebutuhan caregiver skizofrenia. Retrieved from: http:// repository.ui.ac.id/contents/koleksi/16/9206 49bce7abf0078ce040c07985ec537db81c67. pdf.html(20/11/14).

Kartikasari. (2017). Pengaruh terapi psikoedukasi keluarga terhadap self efficacy keluarga dan sosial okupasi klien schizophrenia. Jurnal Majalah Keperawatan, $5(2)$.

Keliat, B.A.(2002). Managemen keperawatan psikososial \& kader kesehatan jiwa CMHN (Intermediate Course). Jakarta : EGC.

Kementrian Kesehatan RI. (2016). Profil kesehatan Indonesia 2015. Jakarta: Kementrian Kesehatan RI.

Maramis, A. (2014). Skizofrenia dan pentingnya layanan kesehatan jiwa. Retrieved from: http://www.tempokini. com/2014/10/skizofrenia-dan-pentingnyalayanan-kesehatan-jiwa/.html(9/4/17). 
Bambang Eryanto: Comparison of Mirror and Video Methods in Increasing Caregiver Knowledge

Maulana. (2009). Manajemen sumber daya manusia. Jakarta: Salemba Empat.

Mboi. (2016). Riset kesehatan dasar: Riskesdas 2013. Retrieved from: http:// www.depkes.go.id/resources/download/ general/Hasil\%20 Riskesdas\%202013.pdf. $\operatorname{html}(5 / 4 / 16)$.

Metkono. (2014). Hubungan tingkat pengetahuan dan beban caregiver dengan perilaku caregiver dalam merawat pasien relaps skizofrenia di Poliklinik Psikiatri Rumah Sakit Dr. H. Marzoeki Mahdi Bogor 2014. Retrieved from: http://ejournal.stiksintcarolus.ac.id/file.php? file = mahasiswa $\& \mathrm{id}=495 \& \mathrm{~cd}=0 \mathrm{~b} 2173 \mathrm{ff} 6 \mathrm{ad} 6 \mathrm{a} 6 \mathrm{fb} 09 \mathrm{c} 95 \mathrm{f} 6 \mathrm{~d} 50$ 001df6\&name $=$ ARTIKEL $\%$ 20ILMIAH $\% 20$ NOVIA $\% 20$ B RIGITA \% 20 SARI $\% 20$ METKONO.pdf.html(8/10/14).

Muhdhar. (2012). Penerapan DVD 6M pendidikan kepada masyarakat dalam pengelolaan sampah rumah tangga. Jurnal FKIP UNS.

Notoatmodjo. (2012). Pendidikan dan perilaku kesehatan. Jakarta: Rineka Cipta.

Nursalam \& Ferry, E. (2009). Pendidikan dalam keperawatan. Jakarta: Salemba Medika.

Pitaloka. (2016). Pengidap gangguan jiwa di Jawa Barat naik 63 persen. Retrieved from: http://www.cnnindonesia.com/ nasional/20150311162100-20-38441/ pengidap-gangguan-jiwa-di-jawa-barat-naik63-persen/.html(5/4/16).

Purnama, A.P. (2013). Efektifitas penggunaan media video dan media leaflet terhadap perubahan pengetahuan dan sikap siswa tentang bahaya NAPZA di SMPN 3 Mojosongo Boyolali. Retrieved from: http:// eprints.ums.ac.id/27215/.html(12/8/17).

Rani, P. (2013). Effect of video-assisted teaching on knowledge of family welfare measure among primigravidae in Kanyakumari Distrik. The Author Is Lecture, Obstetrics \& Gynecological Nursing, Doctors College Of Nursing, Pudukkottai (TN), NJI-
OCT.

Sardiman, A.M. (2012). Interaksi dan motivasi belajar mengajar. Jakarta: PT Raja Grafido Perkasa.

Setiawati \& Dermawan. (2008). Proses pembelajaran dalam pendidikan kesehatan. Jakarta: Trans Info Media.

Stuart \& Laraia. (2013). Principles and practice of psychiatric nursing. Elsevier Mosby. Alih Bahasa Budi Santosa. Philadelphia.

Stuart, G.,W. 2016. Keperawatan kesehatan jiwa. Indonesia: Elsever.

Sulistiowati. (2010). Pengaruh acceptance and commitment therapy terhadap gejala dan kemampuan klien dengan resiko perilaku kekerasan. Jurnal Keperawatan Jiwa Persatuan Perawat Nasional Indonesia (PPNI), 2(1). Retrieved from: https:// repositori.unud.ac.id/protected/storage/ upload/repositori/04b3d6017208b1 fae157ea 7e8fdc8ef1.pdf.html(25/9/16).

Sunaryo. (2004). Psikologi untuk keperawatan. Jakarta : EGC.

Suryani. (2013). Setiap tahun penderita gangguan jiwa di indonesia terus meningkat. Retrieved from: http://www.unpad.ac.id/ profil/dr-suryani-skp-mhsc-setiap-tahunpenderita-gangguan-jiwa-di-indonesia-terusmeningkat/.html(10/4/16).

- (2018). Proses terjadinya $\overline{h a l u s i n a s i}$ sebagaimana diungkapkan oleh penderita skizofrenia. Retrieved from: http://pustaka.unpad.ac.id/wp-content/ uploads/2015/04/3-Proses-terjadinyahalusinasi.pdf.html(2/5/18).

Wawan, A., \& Dewi, M. (2010). Teori dan pengukuran pengetahuan, sikap dan perilaku manusia. Yogyakarta: Nuha Medika.

Williams, M.A. (2010). Knowledge, attitudes, and practices (KAP) of hygiene among school children in Angolela, Ethiopia Published in final edited form as: Prev Med 
Bambang Eryanto: Comparison of Mirror and Video Methods in Increasing Caregiver Knowledge Hyg. June 2010. 